\title{
RIGHTS OF WOMEN DURING PRE-MARRIAGE FROM QUR'ANIC PERSPECTIVES WITH CROSS-REFERENCE TO THE LAW IN MALAYSIA: AN ANALYSIS
}

\author{
Nadzrah Ahmad ${ }^{1}$, Rahmawati Mohd Yusoff ${ }^{2}$, Mohammad Hidir Baharudin ${ }^{3}$
}

1 Assistant Professor, Dept. of Quran and Sunnah Studies, Kulliyyah of Islamic Revealed Knowledge and Human Sciences, International Islamic University Malaysia, 50728 Jalan Gombak, Kuala Lumpur, Malaysia Email: anadzrah@iium.edu.my

2 Postgraduate Candidate, Dept. of Quran and Sunnah Studies, Kulliyyah of Islamic Revealed Knowledge and Human Sciences, International Islamic University Malaysia, 50728 Jalan Gombak, Kuala Lumpur, Malaysia Email: rahmawatimohdyusoff@gmail.com

3 Postgraduate Candidate, International Islamic University Malaysia, 50728 Jalan Gombak, Kuala Lumpur, Malaysia

Email: mohammadhidirbaharudin@gmail.com

\section{Article Info:}

Article history:

Received date: 04.03.2020

Revised date: 11.03.2020

Accepted date: 29.03.2020

Published date: 10.06.2020

\section{To cite this document:}

Ahmad, N., Yusoff, R. M., \& Baharudin, M. H. (2020). Rights of Women During Pre-Marriage from Qur'anic Perspectives with CrossReference to the Law in Malaysia: An Analysis. International Journal of Law, Government and Communication, 5 (19), 01-09.

DOI: $10.35631 /$ IJLGC.519001.

\begin{abstract}
:
Women's rights issues have marked their spot as one of the most debated issues throughout the centuries. Whenever the issue is raised, the topic of marriage is the most highlighted concerning the discussion. Marriage is regularly portrayed as an "oppressive sphere" for women, with their rights being oppressed since the moment of pre-marriage, especially in Islam. However, further reflection on the issue has shown that Islamic matrimony liberates women, preserves their honour and place in society, and abolishes injustice when guided in principle from the Qur'an and the Sunnah of Prophet Muhammad (PBUH) which will be examined in this research. The paper will also analyse the issue in the law of Malaysia and supported by the case law if any. In addition, reference will also be made to the opinions of the scholars regarding the conflicting issue of the rights of women during pre-marriage. Regrettably, Muslims' misunderstanding due to cultural interpretation and mispractice of original Islamic teachings have tainted the true Islamic ideal. It is hoped that the study may provide a clear reference and guideline regarding the rights of women during pre-marriage from both the Islamic and Malaysian laws as this topic is highly significant and beneficial to numerous parties in the present day.
\end{abstract}

Keywords:

Pre-Marriage, Women's Rights, Islam 


\section{Introduction}

Women's rights issues have been an ongoing debate irrespective of the achievements that have been made. Oppression, double standards and domestic violence against women, unfortunately, remain realities in many parts of the world. Marriage has taken centre stage in women's rights issues and is being portrayed as a patriarchal institution which has confiscated women's rights and retarded women's empowerment (Brake, 2012).

Islam has freed women from such oppression and has given them clear rights as delineated in the Qur'an and Sunnah. Islam establishes equality between genders. However, with time and the rapid spread of Islam, many of its teachings have become distorted and misinterpreted. These misconceptions have led many feminists to portray Islam as a religion that suppresses women on account of what is perceived as its many patriarchal practices and policies (Inhorn, 1996).

\section{The Right of Women During Pre-Marriage}

Islam perceives marriage as a crucial institution that ensures the continuity of the human race through procreation. Marriage is the key to a healthy and stable society. Equality in Islam should be understood based on the complementary roles played by each gender. Allah says in the Qur'an of the essence of equality clearly:

"O mankind, indeed, We have created you from male and female and made you peoples and tribes that you may know one another. Indeed, the most noble of you in the sight of Allah is the most righteous of you. Indeed, Allah is Knowing and Acquainted." (Al-Hujurat, 49:13).

Allah the Exalted declares to mankind that He has created them all from a single person, Adam, and from that person, He created his mate, Hawwa. From their offspring, He made nations, comprising tribes, which includes subtribes of all sizes. It was also said that nations refer to non-Arabs, while tribes refer to Arabs. Therefore, all people are the descendants of Adam and Hawwa and share this honour equally. The only difference between them is in the religion that revolves around their obedience to Allah the Exalted and their following of His Messenger (Ibn Kathir, 1419H).

Islam has preserved the rights of each gender to ensure that the objectives of marriage are achieved. Islam has granted women rights from the moment of their birth, and they have rights to choose their suitor for marriage as well as rights as a wife and mother.

\section{First: Right to Get Married and Give Consent to Marriage}

Numerous injunctions in the Qur'an and Sunnah establish a clear right of consent of women regarding marriage. Allah says in the Qur'an:

"O ye who believe! Ye are forbidden to inherit women against their will. Nor should ye treat them with harshness, that ye may take away part of the dower ye have given them, except where they have been guilty of open lewdness; on the contrary live with them on a footing of kindness and equity. If ye take a dislike to them it may be that ye dislike a thing, and Allah brings about through it a great deal of good." (An-Nisa', 4:19).

Previously, the practice was that when a man dies, his male relatives used to have the right to do whatever they wanted with his wife. If one of them wants, he would marry her, give her in marriage, or prevent her from marriage, for they had more right to her than her own family. Thereafter, this verse was revealed about this practice. Allah commands: Do not treat the 
woman harshly so that she gives back all or part of the dowry that she was given, or forfeits one of her rights by means of coercion and oppression, and also live with them honourably, by saying kind words to them, treating them kindly and making your appearance appealing for them, as much as you can, just as you like the same from them. Allah also says that your patience, which is demonstrated by keeping wives whom you dislike, carries good rewards for you in this life and the Hereafter. Ibn "Abbas commented on this verse, "That the husband may feel compassion towards his wife and Allah gives him a child with her, and this child carries tremendous goodness (Ibn Kathir, 1419H)."

Allah says:

"Women impure are for men impure, and men impure for women impure and women of purity are for men of purity, and men of purity are for women of purity: these are not affected by what people say: for them there is forgiveness, and a provision honourable." (An-Nur, 24:26).

Ibn 'Abbas said, "Evil words are for evil men, and evil men are for evil words; good words are for good men and good men are for good words. This was revealed concerning 'Aishah and the people of the slander." He interpreted the verse to mean that evil speech is more suited to evil people, and good speech is more suited to good people. What the hypocrites attributed to 'Aishah was more suited to them, and she was most suited to innocence and having nothing to do with them. 'Abd al-Rahman bin Zayd bin Aslam said, "Evil women are for evil men and evil men are for evil women, and good women are for good men and good men are for good women." This also necessarily refers back to what they said, i.e., Allah would not have made 'Aishah the wife of His Messenger unless she had been good because he is the best of the best of mankind. If she had been evil, she would not have been a suitable partner either according to His Laws or His decree (Ibn Kathir, 1419H).

Allah also says:

"Marry those among you who are single, or the virtuous ones among yourselves, male or female: if they are in poverty, Allah will give them means out of His grace: for Allah encompasseth all, and he knoweth all things." (An-Nur, 24:32).

This is a command to marry 'Ali bin Abi Talhah reported from Ibn 'Abbas: "Allah encouraged them to get married, commanded both free men and servants to get married, and He promised to enrich them." It was recorded that Ibn Mas'ud said: "Seek the richness through marriage, for Allah says: (If they be poor, Allah will enrich them out of His bounty)." It was reported from al-Layth from Muhammad bin 'Ajlan from Sa'id al-Maqburi from Abu Hurayrah that the Messenger of Allah said: "There are three whom it is a right upon Allah to help; one who gets married seeking chastity; a slave who makes a contract with his master with the aim of buying his freedom; and one who fights for the sake of Allah." The Prophet performed the marriage of a man who owned nothing but his waist wraps and could not even buy a ring made of iron, but he still married him to a woman, making the mahr his promise to teach her whatever he knew of the Qur'an. And it is known from the generosity and kindness of Allah that He provided him with whatever was sufficient for her and for him (Ibn Kathir, 1419H).

The Qur'an says:

"When they divorce women, and they fulfil the term of their ('iddah), do not prevent them from marrying their (former) husbands, if they mutually agree on equitable terms. This instruction 
is for all amongst you, who believe in Allah and the Last Day. That is (the course Making for) most virtue and purity amongst you and Allah knows, and ye know not." (Al-Baqarah, 2:232).

'Ali bin Abu Talhah reported that Ibn "Abbas said, "This verse was revealed about the man who divorces his wife once or twice and her 'iddah finishes. He later thinks about taking her back in marriage and the woman also wishes that, yet, her family prevents her from remarrying him. Hence, Allah prohibited her family from preventing her." Masruq, Ibrahim al-Nakha'i, Al-Zuhri and Al-Dahhak stated that this is the reason behind the revelation of this verse. These statements clearly conform to the apparent meaning of the verse. The verse also indicates that the woman is not permitted to give herself in marriage. Rather, she requires a wali (guardian such as her father, brother, adult son, and so forth) to give her away in marriage. This instruction is an admonition which gives meaning, prohibiting a third-party from preventing the women from marrying their ex-husbands, if they both agree to it. Then, obeying Allah's Law by returning the women to their ex-husbands, and abandoning one's displeasure, is purer and cleaner for the outsider's heart, as Allah knows the benefits one gains from what $\mathrm{He}$ commands and what He forbids, while one does not know the benefits of what one does or what one refrains from doing (Ibn Kathir, 1419H).

The admonition is also corroborated by several traditions of the Messenger of Allah (PBUH). Narrated by Abu Hurayrah: The Prophet (PBUH) said:

"A matron should not be given in marriage except after consulting her; and a virgin should not be given in marriage except after her permission.". The people asked, "O Allah's Messenger (PBUH)! How can we know her permission?"? He said, "Her silence (indicates her permission)." (Al-Bukhari, Vol. 7, Book 62, Hadith no. 67).

This hadith shows that permission is one of the vital elements in marriage. A matron must express her opinion regarding the marriage. However, for a virgin, the family can deduce her permission by her silence.

The injunctions of the Qur'an and Sunnah clearly indicate that women have the rights to reject marriage proposals and cannot be forced by others, even her parents. If a forced marriage is to occur, Islam gives the woman the option to nullify the marriage if she is not pleased (Muhammad Saalih Al-Munajjid, 2011).

It was narrated that Buraydah ibn al-Haseeb said:

"A girl came to the Prophet (PBUH) and said: My father married me to his brother's son so that he might raise his own status thereby. The Prophet (PBUH) gave her the choice, and she said: I approve of what my father did, but I wanted women to know that their fathers have no right to do that." (Ibn Majah, Vol. 3, Book 9, Hadith no. 1874).

In many cases, arranged marriages have been construed as forced marriages despite being consensual. This is supported by research done by Professor Paul Gwynne in his book 'World Religions in Practice: A Comparative Introduction' quoted by Khaleef Karim (2013), which presents a compelling misunderstanding between an arranged marriage and forced marriage in Islam where he argues that an arranged marriage is not a forced marriage:

"Marriage is considered to be of the utmost importance in Islam and there is extensive material in both the Qur'än and the hadith on the vital role it plays in the life of faith... On the horizontal 
plane, marriage is a legal contract between two individuals. In this sense, it requires the usual elements of any contract: mutual consent between the parties, specified conditions, and public witness..._However, an arranged marriage is not a forced marriage and Islamic law stipulates that the free consent of both parties is necessary for its validity, even if the bride acts through her official guardian, or wali."

The lack of awareness of Muslim parents plays a vital part in this mishap in the Muslim world. They need a wake-up call in this regard. Islam places a vital role on parents regarding their children's marriage but more as a guide, not as decision makers. Although parents play a major part, the final decision is up to their children. The Qur'an firmly asserts that marriage is a relation based on love, mutual care, consideration and respect. It is not solely sexual. Allah says:

"And of His signs is that He created for you from yourselves mates that you may find tranquillity in them; and He placed between you affection and mercy. Indeed, in that are signs for a people who give thought." (Al-Rum, 30:21).

A major issue in Islamic marriage is the forced marriage. Forced marriages are continually associated with Muslim practices due to the high number of forced marriage cases in Muslim countries. The Forced Marriage Unit (FMU) (2015), reported the highest number of forced marriage cases was in Pakistan with 539 recorded cases (44\%) in 2015, followed by Bangladesh with 89 cases (7\%), India with 75 cases (6\%), Somalia with 34 cases $(3 \%)$ and Afghanistan with 21 cases (2\%). The issue intensified when major Muslim countries who were CEDAW (Convention on the Elimination of All Forms of Discrimination Against Women) signatories refused to associate and therefore applied reservation to Article 16(1)(b), "The same right freely to choose a spouse and to enter into marriage only with their free and full consent." (Cavendish Corporation, 2011).

However, the Shafie scholars stated that there are seven conditions that allow the guardian to marry off his daughter without her permission. Firstly, there is no apparent enmity between the father and daughter. Secondly, the candidate is competent. Thirdly, the candidate marries her with a mahr misl. Forthly, the dowry must be in the country's currency. Fifthly, the candidate must be able to pay a dowry. Sixthly, it is not permissible to marry her to someone who will harm her life such as a blind person or a very old man. Last but not least, the daughter is not a person who is obliged to perform the hajj. Although the hajj is not obligatory, the husband may forbid it because the hajj needs a long period to be completed (Al-Zuhaili, n.d).

It follows that this exception is only limited to the wali mujbir, who are the father and grandfather. So, when the marriage is solemnised by other than them, then it is obligatory to request approval from the daughter (Al-Zuhaili, n.d).

It must be noted that the power that is used by wali mujbir differs from the term forced marriage. The decision taken by wali mujbir is based on the principle of responsibility of the guardian to the daughter, and for the maslahah (benefit) of the child, who is not competent, for example because of young age, mental illness and other circumstances (Al-Zuhaili, n.d). In contrast, a forced marriage is one when the daughter is forced to marry and the marriage does not bring maslahah to her, but instead causes harm to her.

Next, if the wali refuses to marry off his daughter, the authority of the wali will be transferred to wali sultan or hakim (Al-Zuhaili, n.d). There is no dispute among the scholars that the sultan 
has the right to marry off a woman when she has no wali based on the Hadith narrated by Aishah that the Messenger of Allah (PBUH) said:

"Any woman whose marriage is not arranged by her guardian, her marriage is invalid, her marriage is invalid, her marriage is invalid. If (the man) has had intercourse with her, then the mahr belongs to her in return for his intimacy with her. And if there is any dispute then the ruler is the guardian of the one who does not have a guardian." (Ibn Majah, Book 9, Hadith 1953).

In Islamic Family Law (Federal Territory) Act 1984 (Act 303) (IFLA), Section 2 has provided the meaning of wali mujbir as the father or paternal grandfather and above. While wali raja means a wali authorised by the Yang di-Pertuan Agong or by the Ruler, to give away in marriage a woman who has no wali from nasab.

It follows that Section 7 IFLA has discussed the person who has an authority to solemnise the marriage i.e. the wali in the presence of the Registrar, the representative of the wali in the presence and with the permission of the Registrar, or the Registrar as the representative of the wali, or wali raja.

Next, Section 13 of IFLA has also stated that a marriage shall not be recognised unless both parties of the marriage have consented, and either the wali of the woman has consented, or the Shariah Judge has granted his consent as wali raja.

In addition, if the wali refuses to marry his daughter off, the Act has provided the procedure for applying for a wali hakim or wali sultan in Section 18 of the said Act (IFLA).

In the case of Ramli bin Abdul Rahman lwn Marlia Akmar binti Ramli 30 JH (II) 199 (2010) provided that a woman can request for a wali hakim if her wali refuses to marry her off. In this case, the respondent also stated that her future husband is worthy and fit for her. Therefore, the court permitted her to use a wali hakim although her father refused to solemnise her marriage.

The law also explains the condition if the woman who intends to marry is still a child. The minimum age for marriage is sixteen years old. Any prospective brides under the age of sixteen must ask permission from the court (Section 8, IFLA).

It can be said that consulting the woman before marriage fulfils the principle of maqasid shariah in protection of religion and lineage. This practice is able to transform the nonMuslims' negative perceptions into positive ones, regarding tolerance as one of the principles of Islam and the prohibition of coercion and force in marriage. In addition, Islam also protects the principle of lineage because the right of children begins from the moment of choosing the spouse. If the element of forced marriage has been practised, a possibly loveless marriage may affect the children born from that marriage.

\section{Second: Returning of Mahr and Gifts in the Case of Breach of Betrothal}

Betrothal or engagement takes place in order to show the desire of a man to marry a certain woman, therefore, it is to inform that woman and her guardian. This information may be conveyed directly by the man, or his family. It follows that if the woman agrees to his proposal, the engagement between them will take place 9Al-Zuhaili, n.d). 
The wisdom behind the betrothal is like other precepts, which is a way for the engaged couple to get acquainted with each other, allowing the study of the attitude and behaviour of the parties, their nature, and tendencies, but to the extent permitted by the Shariah. The engagement will assure the parties that they are able to lead a life together full of peace, security, happiness, harmony, tranquillity, and love, which is the goal of all persons and their families (Al-Zuhaili, n.d). Allah says in the Qur'an:

\section{“O ye who believe! Fulfil (all) obligations.” (Al-Maidah, 5:1).}

Ibn 'Abbas, Mujahid and others said that obligations here means treaties. Ibn Jarir mentioned that there is a consensus on this view. Ibn Jarì further exemplifies the treaties with the alliances that they used to conduct (Ibn Kathir, 1419H). An-Nawawi (Book 18, Hadith 1780) reported that 'Uqbah bin 'Amir (May Allah be pleased with him) said: The Messenger of Allah (PBUH) said:

"A Mu'min is the brother of another; Mu'min; and thus it is not permissible for a Mu'min to make an offer while the offer of his brother is pending, nor should he make a proposal of marriage while that of his brother is pending till he withdraws his proposal." (Muslim)

In other hadith, from Malik (Book 28, Hadith 1094), from Muhammad ibn Yahya ibn Habban from al-Araj from Abu Hurayrah, that the Messenger of Allah (PBUH) said:

\section{"Do not ask for a woman in marriage when another Muslim has already done so."}

On the issue of any of the parties breaching the betrothal with the mahr being given before marriage, the man can ask the woman to return the mahr, regardless which party is in default. However, for the marital gifts that have been given during betrothal, the scholars differ in their opinions.

Hanafi scholars are of the opinion that a man has the right to ask the woman to return the gifts. However, if the gift is a perishable item such as food, the man has no right to demand the item's return. Malikiyyah scholars posit that if a man is the party in default, he loses his right to ask the woman to return the gift. However, if the woman is the party in default, the man is eligible for the return of the gift. The Hanabilah opines that a man can reclaim the gifts he has sent to the woman. Similarly, the Hanabilah, the Shafie scholars are of the opinion that a man can ask the woman to return the gifts but with an added justification, i.e., he has given the gifts with the intention to marry her. However, according to the Shafie scholars, if the gifts have been damaged, he can seek compensation for them. The preferable view according to al-Zuhaily is that the woman has the right over the gifts. On marital gift reclaiming, Morocco follows the opinion of the Malikiyyah, while Jordan and Syria follow the Hanafiah (Al-Zuhaili, n.d).

In Malaysia, the law on this issue seems to follow the opinion of the Malikiyyah which has stated that if a person has entered into a betrothal and subsequently refuses without lawful reason to marry the other party, the party in default shall be liable to return the betrothal gifts, or the monetary value thereof and to repay the amount of money that have been expended by the other party in preparation for the marriage (Section 15, IFLA).

In the case of Salbiah Othman lwn Hj. Ahmad Abdul Ghani 22 JH (I) 114 (2006), the court asked the party in default (man) to pay the woman compensation for the expenses spent in the preparation for the betrothal and wedding ceremony, totalling to RM6277.10. 
This principle on gifts or monetary compensation fulfils the principle of maqasid shariah in the protection of religion, property, and dignity because Islam teaches its believers to fulfil promises. Islam also outlines the concept of ownership of property by stating that the gifts should be owned by their rightful owner. The scholars hold different opinions on whether the rightful owner should be the man or the woman. In addition, the dignity of the spouse is also being protected because by nullifying the engagement, the party who is not in default will experience shame and in certain circumstances, may be subjected to negative perceptions of himself or herself in the public eye.

\section{Conclusion}

Islam has granted women voice and rights. However, its rapid expansion has led to a corruption of its teachings particularly due to cultural influences. Islamic teachings have been mixed with patriarchal cultures which are often given priority over the correct understanding of Islamic teachings. It is important to be aware of the rights Islam has given women before, during and after marriage. Such awareness will help reduce the injustices perpetrated against women in the name of Islam.

\section{Acknowledgement}

This research is supported by Ministry of Higher Education under Fundamental Research Grant Scheme (FRGS) with title: A Framework of Women Empowerment and Inclusive Development to Enhance Economic Involvement and Social Rights Towards Preventing Domestic Violence (FRGS19- 192-0801).

\section{References}

\section{$\underline{\text { Statutes }}$}

Islamic Family Law (Federal Territory) Act 1984 (Act 303).

\section{Books and Articles}

Al-Bukhari, Abu 'Abd Allah Muhammad ibn Isma'il ibn Ibrahim ibn Al-Mughirah ibn Bardizbah Al-Ju'fi. (1422H). Sahih Al-Bukhari. N.p.: Dar Tuq Al-Najah.

Al-Quran Karim.

Al-Zuhaili, Wahbah bin Mustafa. (n.d). al-Fiqh al-Islami wa Adillatuhu. Dimashq: Dar al-Fikr Forced Marriage Unit Statistic 2015. (2016). Foreign and Commonwealth Office, https://www.gov.uk/government/uploads/system/uploads/attachment_data/file/505827 /Forced_Marriage_Unit_statistics_2015.pdf. Retrieved on September 6, 2016

An-Nawawi, Abu Zakaria Mahyuddin Yahya. (2011). Riyad As-Salihin. Kuwayt: Jam'iyah Ahya' al-Turath al-Islami.

Brake, Elizabeth. (2012). Minimizing Marriage: Marriage, Morality, and the Law. New York: Oxford University Press.

Cavendish Corporation. (2011).

Ibn Kathir, Abu al-Fidak Ismail bin Umar bin Kathir al-Qurshi al-Basori thumma ad-Damshiqi. (1419H). Tafsir al-Quran al-A'zim. Beirut: Dar al-Kutb al-Ilmiyyah.

Ibn Majah, Abu 'Abdillah Muhammad ibn Yazid ibn Majah Al-Rab'i Al-Qazwini. (2009). Sunan Ibn Majah. N.p.: Dar Al-Risalah Al-'Alamiyyah.

Inhorn, Maria C. (1996). Infertility And Patriarchy: The Cultural Politic Of Gender And Family Life In Egypt. Philadelphia: University of Pennsylvania Press.

Khaleef Karim. (2016). Islam on Forced Marriage. https://discover-the truth.com/2013/12/15/islam-on-forced-marriages/. Retrieved on August 25, 2016. 
Malik ibn Anas. (2001). Muwatta' Imam Malik. Beirut: Dar al-Fikr.

Muhammad Saalih Al-Munajjid. (2016). Islam Question and Answer. https://islamqa.info/en/163990. Retrieved on September 1, 2016.

\section{Cases}

Ramli bin Abdul Rahman lwn Marlia Akmar binti Ramli, 30 JH (II) 199 (2010).

Salbiah Othman lwn Hj. Ahmad Abdul Ghani, 22 JH (I) 114 (2006). 